\section{Barriers to the importation of medical products to Russia: in search of solutions}

\author{
Sergei V. Jargin \\ Department of Pathology, People's \\ Friendship University of Russia, Moscow, \\ Russia
}

\begin{abstract}
Barriers to the importation of foreign medical products to Russia contribute to higher prices on the domestic market, which is a disadvantage for healthcare. Such barriers, valid also for the import of professional literature, resulted in persistence of some outdated concepts and methods in medicine. Policies promoting domestic medical products can result in their biased characterization in scientific reports. In conclusion, more international trust is needed for successful co-operation on the lawful basis and elimination of unfair practices in the interests of healthcare and medical research.
\end{abstract}

\section{Introduction}

Some papers ${ }^{1,2}$ have already discussed the complicated mechanisms of registration, certification and custom clearance of medical products imported to Russia. Indeed, in order to be sold in Russia, a medical product must be registered with the Ministry of Health. For that purpose, the manufacturer must provide numerous documents translated into Russian, certified by a notary or court, and for some countries also by the consular section of a Russian embassy. Documents and translations, often bearing more than 10 seals on both sides, expire after some time, and the procedures must be repeated. Obviously, it is time for the authorities engaged in international economical relations to consider acceptance of documents in English, which is an international language.

\section{Red-tape and corrupt practices}

For a medical product to be registered, technical, hygienic, toxicological, clinical and other assessments must be performed in a center for expertise of medical products and other institutions. The person presenting the documents to the authorities must be a Russian subject, registered with the official structures.
Furthermore, custom clearance becomes more intricate with time, thus requiring voluminous paperwork. There is a policy of preference for domestic products, e.g. in the presence of a domestic analogue, a foreign product is not allowed to be presented, although its quality might be higher. Furthermore, apart from lawful custom duties, which are relatively high, unofficial payments are taken not only by customs but also by other involved authorities. In some cases, foreign manufacturers are informed about it by mediator firms, though, having no choice but to pay, they become embroiled in corrupt interactions. ${ }^{1,2}$ There are many additional difficulties making the procedures of registration, certification and custom clearance more intricate. A former custom official and co-director for relation with the customs said from the tribune (at the conference Localization of the medical equipment in Russia held in Moscow on 5 December 2012)(Deutsch-Russische Auslandshandelskammer 2012, unpublished data) that the process of custom clearance is so intricate that it is in any case advisable to hire a custom broker or engage a mediator firm in order to export a medical product to Russia.

Mediator firms offer assistance in registration, certification, and custom clearance of medical products. In return, exclusive distributor's rights are sometimes requested from the manufacturer. In this way, the mutuality principle of exclusive rights is violated: some mediator firms make use of exclusive distributor's rights from several manufacturers at the same time. Numerous custom brokers and mediator firms are profiting from the artificial barriers to the importation of medical products. Unofficial payments are sometimes overtly mentioned in business correspondence. The documents shown in Jargin, ${ }^{2}$ together with other evidence, were forwarded to the Ministry of Health. As far as we know, no measures have been taken. Moreover, the manager of the mediator firm, where the informant had been employed, was informed about his letter to the Ministry, which resulted in mobbing and dismissal. This scenario was repeated later in another firm, after the authorities were informed about bribes at the customs.

Protectionism can be justified under certain conditions in order to protect domestic manufacturers. However, when protectionism is coupled with corruption, it is hardly acceptable from the viewpoint of medical ethics: difficulties and excessive expenditures in the process of import result in price elevation for medical products in the domestic market, thus making them less available for the patients. The policy promoting domestic medical products can include indirect pressure on researchers, resulting in a biased characterization of such products in scientific publications, ${ }^{3-5}$ which, in turn, are used for official registration of subop-
Correspondence: Sergei V. Jargin, Department of Pathology, People's Friendship University of Russia, Miklukho-Maklaya str. 6, 115184 Moscow, Russia.

Tel. +7.495.434.5300 - Fax: +7.495.433.1511.

E-mail: sjargin@mail.ru

Key words: international trade, Russia, medical products.

Conflict of interests: the author declares no potential conflict of interests.

Received for publication: 14 December 2012.

Revision received: 19 February 2013.

Accepted for publication: 28 February 2013.

This work is licensed under a Creative Commons Attribution 3.0 License (by-nc 3.0).

CC Copyright S.V. Jargin, 2013

Licensee PAGEPress, Italy

Healthcare in Low-resource Settings 2013; 1:e13 doi:10.4081/hls.2013.e13

timal products. Misleading advertising of medical products and services is widespread and regarded as a norm. Some physicians manipulate their patients to make them purchase the medicines they promote. Distributing, mediating, brokerage and other firms are proliferating. Moreover, invasive procedures without sufficient clinical indications are sometimes applied with the actual purpose of registering a suboptimal domestically-produced medicine. ${ }^{3}$ On the occasion of the above-mentioned conference, another speaker answered the question Why not to simplify the custom clearance and certification procedures in the interests of patients? with the following: Then domestic manufacturers will have no chance (Deutsch-Russische Auslandshandelskammer 2012, unpublished data). At the same conference, the fact of corruption was mentioned several times as if it were a norm. Certainly, imported products need to be evaluated before admittance to the domestic market; however, in conditions of corruption and insufficient competence of supervising authorities, placebos and doubtful medications, both domestic and imported ones, are permitted for the clinical use. ${ }^{4,5}$

There is also the reverse of the medal. Fraud is widespread all over the world, and skills are developing not only in the field of fraud itself but also for its adaptation to laws and regulation, so that fraudulent intentions are difficult to prove. ${ }^{6}$ There is a dichotomy in the intellectual endeavor: some experts improve their professional knowledge in the interests of science and public health, while others develop their fraudulent skills. Moreover, considering judicial proficiency of some fraudsters and free time they dispose of, it can be difficult and 
frustrating to prosecute them in conditions of strict lawfulness. Under such circumstances, societal institutions and authorities should dispose of mechanisms to defend public interests from fraudsters, if even the latter act prima facie in accordance with the laws and regulations. Paradoxically, some arguments in favor of lawlessness and even corruption are not easy to dismiss: if fraud is invincible on a global scale, there is no point in locally upholding lawfulness for its own sake. Therefore, more international trust is needed for a successful co-operation on the strictly lawful basis and the elimination of unfair practices in the interests of healthcare and medical research.

\section{Import of professional literature and plagiarism}

Another topic that should be mentioned is plagiarism. Limited access to foreign professional literature, whose import is also hampered by protectionist barriers, has been one of the causes of plagiarism in the former Soviet Union (SU). In a sense, plagiarism has been a substitute for the import of foreign books. Some handbooks issued in Russia have been compiled from foreign editions with verbatim translations and no references given to the sources. Such editions are often poorly illustrated or not illustrated at all, contain mistranslations causing distortion of the meaning and misleading medical practice and research. ${ }^{7}$ Admittedly, professional editions in the international trade are not always perfect, sometimes apparently being of a rough-andready nature, which seems to have worsened during the last decades. What is obviously needed is a kind of a centralized international mechanism supervising research and publication, ensuring their quality, independence from vested interests, and preventing needless parallelism with repetition of experiments, clinical studies and publications.

Some physicians in Russia purchase foreign literature with their own funds. Moreover, books ordered via post or express mail are detained by customs (if the total price is more than 10,000 rubles or about 320 US dollars), and the addressee must go personally to the custom office, pay the VAT (30\% of the price) and a custom fee, and spend much time in queues. The payment is received in another quite distant office, and the receipt is then accepted (stamped for some purpose) in the third office in another part of Moscow. Documentary evidence thereof was published in Jargin. ${ }^{2}$ There is no reasonable explanation why fees cannot be collected at the same place. The procedure takes 2-3 working days, but for a doctor living in a remote place it can be more complicated. The procedure is so intricate that a busy doctor is, in effect, forced to hire a broker. At the same time, it impedes the import of professional literature, which is a disadvantage for healthcare.

\section{Consequences for medical practice}

Protectionism and partial isolation of Russian medicine and medical research from the international community has not remained without consequences for the healthcare. Obviously, it is one of the causes of the relatively low life expectancy. ${ }^{8}$ According to my estimates after practicing pathology abroad for more than seven years, an average size of malignant tumors in routine surgical specimens was at least 2-3 times larger in central Moscow clinics as compared to provincial hospitals in some West European countries, which means that early detection of malignancies is less efficient in Russia. Abroad, almost all mastectomy specimens were without muscle. In Moscow hospitals, the modified radical mastectomy (Patey) with the removal of the pectoralis minor muscle was the standard procedure in the last decades, but the Halsted operation with the removal of both major and minor pectoralis muscles was applied as well. The Halsted operation prevailed earlier; it was recommended by Russian textbooks of surgery and oncology for all types of breast cancer until the late 1990s. It was presented as a key treatment modality for breast cancer even in some handbooks edited after the year 2000.9,10 The shift towards conservation in the treatment of breast cancer in the whole world, including less developed countries, remained largely unnoticed in the former SU for a long time. Moreover, the negative appendectomy rate is higher in Russia than abroad obviously because of persistent outdated concepts of catarrhal, chronic, and non-destructive appendicitis not requiring histopathological evidence of acute inflammation for the diagnosis. ${ }^{11}$

Furthermore, partial gastrectomy was applied for the treatment of duodenal and gastric ulcers abroad much more rarely than in the former SU, and its volume was less extensive. The approach to surgical treatment of gastric and duodenal ulcers in the former SU deviated from international practice. ${ }^{12,13}$ Use of partial gastrectomy for ulcer treatment has remained disproportionately high in many institutions, ${ }^{14}$ owing to technical problems, conservatism among surgeons, ${ }^{12}$ and limited availability of medical therapy. ${ }^{14}$ In the 1960 s, when gastrectomy (removal $2 / 3-3 / 4$ of the stomach) was almost a single surgical treatment modality for ulcer, ${ }^{15}$ about 60,000 of such operations were performed yearly in ulcer patients, while significant complications became obvious. ${ }^{13}$ Later, when adequacy of this concept of ulcer treatment was doubted, responsibility for the hyperradicalism in surgery was, in a veiled form, ascribed to the well-known surgeon Sergei Yudin, who indeed advocated gastrectomy for ulcer treatment, including primary gastrectomy for perforated ulcers. ${ }^{16}$ One of his arguments was the limited availability of regular medical treatment of ulcer in the 1940s' SU, while gastrectomy promised good chances of cure. ${ }^{17} \mathrm{~S}$. Yudin died in 1954; however, instructive publications presenting gastrectomy as a main or single surgical method of ulcer treatment continued to appear long time thereafter. ${ }^{15,18}$ In a textbook of surgery issued in 1995 , the Billroth's operations with removal of $2 / 3$ to $3 / 4$ of the stomach are listed in the first place among the surgical treatment modalities of gastroduodenal ulcers. ${ }^{19}$ Noticeably, a Yudin's paper from the late 1940s, recommending gastrectomy for the treatment of duodenal and gastric ulcers, was reprinted by the main journal of Russian surgeons Khirurgiia in 1991 without criticism but with approving words in the preface. ${ }^{17}$ The so-called administrative factor obviously played its role: ${ }^{12}$ the support of certain methods by healthcare authorities, who sometimes favored less individualized approaches applicable to a large group of patients. This factor obviously contributed also to the high negative appendectomy rate in former SU and the persistence of some outdated practices in other fields of medicine, such as the routinely performed diathermocoagulation or cryotherapy of cervical pseudo-erosions (endocervical ectopia or ectropion) regardless of the presence of epithelial dysplasia. Administrative decisions were efficiently introduced into practice due to the authoritative management style ingrained in Russia.

\section{Conclusions}

In conclusion, barriers to the import of medical products, insufficient availability of international literature and the partial isolation of Russian medicine from the rest of the world have contributed to the persistence of outdated methods in everyday practice..$^{20}$ Admittedly, scientific and educational institutions can have online access to some editions, but many practical physicians and patients have not, thus being easy victims of misleading advertising. At the same time, limited access to international literature has been compensated by Russian editions. For example, a handbook of immunohistochemistry bearing the $\log 0$ of the International Academy of Pathology ${ }^{21}$ contains references to questionable and potentially misleading publications, ${ }^{22-27}$ some of which were previously criticized. ${ }^{28-30}$ 
2010;8:409-10.

\section{References}

1. Jargin SV. Barriers to importation of medical products in Russia. Lancet 2008;372: 1732.

2. Jargin SV. Barriers to importation of medical products in Russia: a comment. Dermatopathol Pract Concept 2010;16:21.

3. Jargin SV. Surfactant preparations for tuberculosis and other diseases beyond infancy: a letter from Russia. Tuberculosis 2012;92:280-2.

4. Jargin SV. Discussion of evaluation of cholesterol-lowering and antioxidant properties of sugar cane policosanols in hamsters and humans. Appl Physiol Nutr Me 2009;34:75-7.

5. Jargin SV. Testing of serum atherogenicity in cell cultures: questionable data published. Ger Med Sci 2012;10:Doc02.

6. Jargin SV. Use of mathematical statistics for quality control of surface lapping and detection of fraud: a case study. Journal of Tribology and Surface Engineering 2012; 3:109-17.

7. Jargin SV. Plagiarism in radiology: a substitute for importation of foreign handbooks. J Med Imag Radiat On 2010;54:50-2.

8. Jargin SV. Health care and life expectancy: a letter from Russia. Public Health 2013;127:189-90.

9. Kovanov VV, Perelman MI. Operations on the chest and thoracic organs. In: Kovanov $\mathrm{V}$, ed. Operative surgery and topographic anatomy. Moscow, Russia: Meditsina; 2001. pp 297-321.

10. Semiglazov VV, Topuzov EE. Breast cancer. Moscow, Russia: Medpress-inform; 2009.

11. Jargin SV. Unnecessary operations: a letter from Russian pathologist. Int J Surg
12. Balalykin DA. [Introduction of pathogenic principles of surgical treatment of ulcer disease in Russian surgery]. [Article in Russian]. Khirurgiia (Mosk) 2004;10:73-8.

13. Balalykin DA. History of surgical treatment of gastric and duodenal ulcers in Russia. Khirurgiia (Mosk) 2001;3:64-6.

14. Lobankov VM. Surgery of ulcer disease on the boundary of XXI century. Khirurgiia (Mosk) 2005;1:58-64.

15. Makarenko TP. Is it necessary to improve the classical method of gastric resection in peptic ulcer? Sov Meditsina 1973;36:46-50.

16. Petrovsky BV. About Sergei Sergeiievich Yudin. In: Yudin SS, ed. Selected works. Moscow, Russia: Meditsina; 1991. pp 35675 .

17. Iudin SS. Essays on gastric surgery. Khirurgiia (Mosk) 1991;7:159-66.

18. Korolev MP. [The surgical treatment of duodenal peptic ulcer. (Materials from the discussion of the problem at the 8th AllRussian Congress of Surgeons, Krasnodar, 21-23 September 1995)]. [Article in Russian]. Vestn Khir Im Grekov 1996;1:96100.

19. Kuzin MI, Chistova MA. The stomach and duodenum. In: Kuzin MA, ed. Surgical diseases. Moscow, Russia: Meditsina; 1991. pp 337-407.

20. Jargin SV. Limited access to the international medical literature in Russia. Wien Med Wochenschr 2012;162:272-5.

21. Petrov SV, Raikhlin NT, eds. Manual on immunohistochemical diagnosis of human tumors. 4th ed. Kazan, Russia: Titul; 2012.

22. Kogan EA, Ugriumov DA. Correlation between proliferative processes and cell death in non-small cell lung cancer with glandular differentiation at different stages of tumor progression. Ark Patol 2002;64:33-6.

23. Kogan EA, Mazurenko NN, Iushkov PV, et al. The immunohistochemistry of cellular oncogenes in precancer and cancer of the lung. Ark Patol 1990;52:3-11.

24. Paltsev MA, Kogan EA, Tuntsova OI. Immunohistochemistry of biomolecular markers of early thyroid cancer. Ark Patol 1997;59:18-23.

25. Pal'tsev MA, Kogan EA, Tuntsova OI, et al. Morphologic and molecular-genetic characteristics of carcinoma, adenoma and surrounding tissue of the thyroid gland. Ark Patol 1998;60:5-10.

26. Kogan EA, Sagindikova GS, Sekamova SM, Jack G. Morphological, cytogenetic and molecular biological characteristics of lung cancer in persons exposed for a long time to radionuclide radiation pollution in the Semipalatinsk region of Kazakhstan. Ark Patol 2002;64:13-8.

27. Vozianov AF, Romanenko AM, Saidakova NA, et al. [Ecological pathomorphosis of renal cell carcinoma in the inhabitants of radiocontaminated regions of Ukraine]. [Article in Russian]. Journal of the Academy of Medical Sciences of Ukraine 2002;8:120-31.

28. Jargin SV. Over-estimation of radiationinduced malignancy after the Chernobyl accident. Virchows Arch 2007;451:105-6.

29. Jargin SV. Overestimation of Chernobyl consequences: biophysical aspects. Radiat Environ Bioph 2009;48:341-4.

30. Jargin SV. Pathology in the former Soviet Union: scientific misconduct and related phenomena. Dermatol Pract Concept 2011;1:16. 